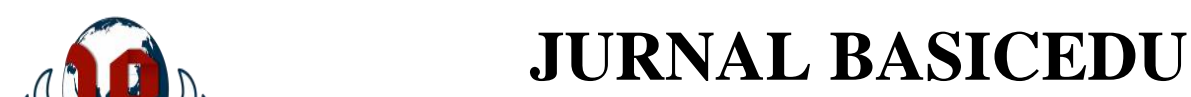

Volume 5 Nomor 3 Tahun 2021 Halaman 1564 - 1576

Research \& Learning in Elementary Education

https://jbasic.org/index.php/basicedu

PNIVERSITAS

hips:/Jbasic.org/index.phplbasicedu

\title{
Pengaruh Keterampilan Manajerial Kepala Sekolah Dan Peran Komite Terhadap Efektivitas Manajemen Berbasis Sekolah
}

\author{
Suyitno ${ }^{凶}$ \\ STIE Indonesia Malang, Indonesia \\ E-mail: drsuyitno@yahoo.co.id
}

\begin{abstract}
Abstrak
Manajemen Berbasis Sekolah merupakan bentuk otonomi manajemen pendidikan pada satuan pendidikan, yang dalam hal ini kepala sekolah atau madrasah dan guru dibantu oleh komite sekolah atau madrasah dalam mengelola kegiatan pendidikan. Tujuan dari penelitian ini antara lain untuk mengetahui dan menganalisis variabel ketrampilan manajerial kepala sekolah dan komite sekolah memiliki pengaruh terhadap efektivitas manajemen berbasis sekolah di SD Negeri Se-Kecamatan Karangrejo. Metode penelitian yang dilakukan dengan rancangan kuantitatif eksplanatori. Teknik pengumpulan data dilakukan dengan kuesioner sebelumnya sudah diuji tingkat validitas dan reliabelitasnya terhadap 60 responden sebagai sampel dalam penelitian ini. Data yang sudah terkumpul selanjutnya dianalisis dengan uji regresi linier berganda dengan bantuan software SPSS versi 17.0. Hasil penelitian diketahui bahwa (1) secara deskriptif variabel efektivitas MBS dalam kategori baik, ketrampilan manajerial kepala sekolah dan peran komite sekolah dalam kategori baik, (2) terdapat pengaruh positif dan signifikan antara ketrampilan manajerial kepala sekolah terhadap efektivitas MBS sebesar 56,8\%, (3) ada pengaruh positif dan signifikan peran komite sekolah terhadap efektivitas MBS sebesar 36,8\%, (4) ada pengaruh positif dan signifikan ketrampilan manajerial kepala sekolah dan peran komite sekolah secara bersama-sama terhadap efektivitas MBS sebesar 63,3\%. (5) Diantara kedua variabel bebas tersebut, ketrampilan manajerial kepala sekolah yang berpengaruh dominan terhadap efektivitas MBS.
\end{abstract}

Kata kunci: Ketrampilan manajerial kepala sekolah, Komite sekolah, Manajemen Berbasis Sekolah.

\begin{abstract}
School-based management is a form of autonomy in education management in educational units, in which case the principal or madrasah and teachers are assisted by the school committee or madrasah in managing educational activities. The purpose of this study, among others, was to determine and analyze the variables of managerial skills of school principals and school committees that influence the effectiveness of school-based management in SD Negeri Se-Karangrejo District. The research method was carried out with an explanatory quantitative design. The data collection technique was carried out by using a questionnaire before the level of validity and reliability had been tested on 60 respondents as the sample in this study. The collected data were then analyzed using multiple linear regression tests with the help of SPSS version 17.0 software. The results showed that (1) descriptively the effectiveness of SBM in good categories, managerial skills of school principals and the role of school committees in good categories, (2) there was a positive and significant influence between principal managerial skills on the effectiveness of SBM by 56.8\%, (3) there was a positive and significant role of the school committee on the effectiveness of SBM by $36.8 \%$, (4) there was a positive and significant influence on the managerial skills of school principals and the role of school committees together on the effectiveness of SBM by 63.3\%. (5) Between the two independent variables, the managerial skills of school principals had a dominant influence on the effectiveness of $S B M$
\end{abstract}

Keywords: Principal's skill managerial, school's Committee, School-Based Management

Copyright (c) 2021 Suyitno

Corresponding author :

Email : drsuyitno@yahoo.co.id

DOI $\quad$ : https://doi.org/10.31004/basicedu.v5i3.970

ISSN 2580-3735 (Media Cetak)

ISSN 2580-1147 (Media Online) 
1565 Pengaruh Keterampilan Manajerial Kepala Sekolah Dan Peran Komite Terhadap Efektivitas Manajemen Berbasis Sekolah - Suyitno

DOI: https://doi.org/10.31004/basicedu.v5i3.970

\section{PENDAHULUAN}

Seiring dengan konsep desentralisasi yang akan melahirkan penerapan otonomi, pengelolaan lembaga pendidikan juga berbenah dan meninjau aturan-aturan kembali yang semula bersifat sentralistik kemudian bergeser menjadi desentaralistik yang menekankan adanya otonomi, fleksibel dan partisipatif. Reformasi pengelolaan lembaga pendidikan dengan pendekatan yang bersifat managerial tersebut dikenal dengan manajemen berbasis sekolah. Undang-Undang No 20 Tahun 2003 tentang Sistem Pendidikan Nasional dinyatakan bahwa pengelolaan pada satuan pendidikan, yang dalam hal ini kepala sekolah atau madrasah dan guru dibantu oleh komite sekolah atau madrasah yang bertujuan untuk merancang kembali pengelolaan sekolah dengan memberikan kekuasaan kepada Kepala Sekolah dalam upaya perbaikan kinerja sekolah yang mencakup guru, siswa, kepala sekolah dan meningkatkan partisipasi masyarakat. Kajian secara empirik yang dilakukan oleh(Sunanto, 2015) mengindikasikan bahwa kemampuan kepala sekolah dan guru ditambah partisipasi masyarakat melalui perannya dalam komite sekolah telah berhasil menunjukkan adanya sinergi, koordinasi, dan dinamisasi dalam konteks manajemen berbasis sekolah. Sementara dalam penelitian lain telah menunjukkan adanya hubungan positif antara penerapan Manajemen Berbasis Sekolah dengan mutu pendidikan, misalkan (Arar \& Nasra, 2020), dan(Atiek Istijarti, 2019).

Menurut Danim dalam (Siti Aminah, 2015), manajemen berbasis sekolah adalah suatu proses kerja komunitas sekolah dengan cara menerapkan kaidah kaidah otonomi, akuntabilitas, partisipasi, dan sustainability untuk mencapai tujuan pendidikan dan pembelajaran secara bermutu. Selain itu menurut Mulyasa dalam (Ibrahim, 2015), manajemen berbasis sekolah adalah konsep yang menggambarkan perubahan formal struktur penyelenggaraan sekolah sebagai suatu bentuk desentralisasi yang mengidentifikasi sekolah itu sendiri sebagai unit utama peningkatan serta bertumpu pada redistribusi kewenangan pembuatan keputusan sebagai sarana penting dalam peningkatan mutu penyelenggaraan pendidikan. Adapun untuk mencapai hasil yang lebih optimal, efektif, dan efisien dalam menangani berbagai permasalahan pendidikan, pemerintah daerah tidak mungkin dapat bekerja secara sendirian. Hal ini dikarenakan masih ada pihak-pihak lain yang berkepentingan (stakeholder) terhadap bidang pendidikan tersebut, seperti orang tua (masyarakat), sekolah (lembaga pendidikan), dan institusi sosial lain, seperti dunia usaha dan dunia industri. Oleh karena itu kerja sama dan koordinasi antara pemerintah daerah dengan pihak-pihak yang berkepentingan menjadi sangat penting dilakukan.

Keterampilan manajerial kepala sekolah merupakan suatu ketrampilan dari seorang kepala sekolah (karakteristik personal) dalam menjalankan tugas manajemen berkinerja tinggi dengan menjalankan fungsifungsi manajemen. Selanjutnya Siagian dalam (Syamsudin, 2017) menyebutkan beberapa kecakapan yang harus dimiliki dalam menjalankan fungsi manajemen antara lain: pertama, kemampuan merencanakan dengan indikator yaitu pertama kemampuan menyusun dan menerapkan strategi, dan mampu mengektifkan perencanaan. Kedua, kemampuan mengoorganisasikan dengan indikator mampu melaksanakan pembagian tanggung jawab dan mampu mengelola personil. Ketiga, kemampuan melaksanakan tugasnya dengan indikator yaitu mampu mengambil keputusan dan mampu menjalin komunikasi. Keempat, kemampuan mengadakan pengawasan dengan indikator mampu mengelola dan mampu mengendalikan operasional serta mampu menjalankan peranannya sebagai manajer agar tujuan yang telah ditetapkan bersama dapat tercapai. Agar seseorang kepala sekolah secara efektif dapat melaksanakan fungsinya sebagai manajer maka kepala sekolah harus juga mampu untuk mewujudkan ke dalam tindakan atau perilaku nilai-nilai yang terkandung di dalam ketiga keterampilan yaitu keterampilan konseptual, keterampilan manusiawi dan keterampilan teknik (Iskandar, 2017). Kemampuan manajerial sangat berkaitan erat dengan manajemen kepemimpinan yang efektif, karena sebenarnya manajemen pada hakekatnya adalah masalah interaksi antara manusia baik secara vertikal maupun horizontal. Oleh karena itu kepemimpinan dapat dikatakan sebagai perilaku memotivasi orang lain untuk bekerja kearah pencapaian tujuan tertentu. 
1566 Pengaruh Keterampilan Manajerial Kepala Sekolah Dan Peran Komite Terhadap Efektivitas Manajemen Berbasis Sekolah - Suyitno

DOI: https://doi.org/10.31004/basicedu.v5i3.970

Perilaku kepala sekolah terletak pada kegiatan melakukan pekerjaan memimpin. Ketrampilan manajerial kepala sekolah pada hakikatnya adalah proses mempengaruhi seseorang atau kelompok dalam usaha-usaha pencapaian tujuan. Kepala sekolah dalam melaksanakan kepemimpinannya dituntut untuk mencapai keberhasilan berbagai hal meliputi keberhasilan dalam mengelola sekolah, keberhasilan dalam kegiatan pembelajaran, mengelola ketenagaan, mengelola sarana dan prasarana, mengelola keuangan, mengelola lingkungan sekolah, serta mengelola hubungan sekolah dengan masyarakat (Ariyanti et al., 2018).

Pada tingkat sekolah, kepala sekolah sebagai figur kunci dalam mendorong perkembangan dan kemajuan sekolah, kepala sekolah tidak hanya meningkat tanggung jawab dan otoritasnya dalam programprogram sekolah, kurikulum dan keputusan personel, tetapi juga memiliki tanggung jawab untuk meningkatkan akuntabilitas keberhasilan siswa dan programnya. Kepala sekolah harus pandai dalam memimpin kelompok dan pendelegasian tugas dan wewenang. Oleh karena itu kepala sekolah harus mempunyai kompetensi yaitu kompetensi kepribadian, kompetensi manajerial, kompetensi kewirausahaan, kompetensi supervisi dan kompetensi sosial (F. A. Siregar, 2018).

Terkait dengan penyelenggaraan pendidikan, sekolah yang efektif adalah sekolah yang meyakini bahwa partisipasi warga sekolah dan masyarakat (komite sekolah) merupakan bagian dari kelangsungan hidup sekolah (Nelliraharti, 2018). Hal ini dilandasi oleh keyakinan bahwa makin tinggi tingkat partisipasi, makin besar rasa memiliki, makin besar pula rasa tanggung jawab dan makin besar pula tingkat dedikasinya. Esensi hubungan sekolah dan masyarakat (komite sekolah) adalah untuk meningkatkan keterlibatan, kepedulian, kepemilikan dan dukungan dari masyarakat terutama dukungan moral dan finasial. Adapun peran tokoh masyarakat yang penting demi kemajuan pendidikan antara lain sebagai penggerak, informan dan penghubung, koordinator dan pengusul(Pakniany et al., 2020).

Komite Sekolah merupakan badan yang bersifat mandiri yang berada di setiap satuan pendidikan, tidak memiliki hubungan yang bersifat hierarkis dengan satuan pendidikan maupun lembaga pemerintah lainnya. Komite Sekolah berfungsi untuk mewadahi peran serta masyarakat dalam rangka meningkatkan mutu, pemerataan, dan efisiensi pengelolaan pendidikan di satuan pendidikan. Keputusan Menteri Pendidikan Nasional No. 44 tahun 2002 dalam (Syamsudin, 2017), pembentukan Komite Sekolah bertujuan yaitu: (a) mewadahi dan menyalurkan aspirasi dan prakarsa masyarakat dalam melahirkan kebijakan dan program pendidikan di kabupaten/kota (untuk Dewan Pendidikan) dan di satuan pendidikan (untuk Komite Sekolah); (b) meningkatkan tanggung jawab dan peran serta aktif dari seluruh lapisan masyarakat dalam penyelenggaraan pendidikan; (c) menciptakan suasana dan kondisi transparan, akuntabel, dan demokratis dalam penyelenggaraan dan pelayanan pendidikan yang bermutu di daerah kabupaten/kota dan satuan pendidikan. Komponen dan indikator kinerja Komite Sekolah terkait pada peran yang dilakukannya sesuai dengan Keputusan Menteri Pendidikan Nasional No 044/U/2002 adalah sebagai badan pertimbaangan (advisory agency), pendukung (supporting agency), pengawas (controlling agency), dan badan mediator (mediator agency). Sementara beberapa kajian menunjukkan hubungan yang sangat signifikan antara komite sekolah dengan keberhasilan MBS antara lain penelitian Siregar (2020), Marsofiyati \& Febriantina, (2016) dan Basith (2020).

Manajemen Berbasis Sekolah merupakan paradigma desentralisasi yang mengacu dalam pemberian wewenang sepenuhnya kepada sekolah itu sendiri dalam mengelola segala kebutuhan operasional sekolah sehingga sekola secara mandiri dapat berkembang dalam mencapai tujuan pembelajaran yang telah ditentukan.Upaya penerapan Manajemen Berbasis Sekolah juga merupakan salah satu kunci keberhasilan sekolah dalam dunia pendidikan sehingga memiliki daya saing yang tinggi.

Menurut Mulyasa dalam Hodin (2020), sekolah yang berhasil dalam menerapkan Manajemen Berbasis Sekolah apabila: 1). Jumlah siswa yang mendapat pelayanan pendidikan semakin meningkat; 2). Semakin terciptanya kegiatan belajar mengajar yang aktif-menyenangkan di semua kelas sepanjang hari;3). Kualitas layanan pendidikan menjadi lebih baik; 4). Tingkat tinggal kelas menurun dan produktivitas sekolah semakin 
1567 Pengaruh Keterampilan Manajerial Kepala Sekolah Dan Peran Komite Terhadap Efektivitas Manajemen Berbasis Sekolah - Suyitno

DOI: https://doi.org/10.31004/basicedu.v5i3.970

baik dalam arti rasio antara jumlah siswa yang mendaftar dengan jumlah siswa yang lulus menjadi semakin besar; 5). Relevansi penyelenggaraan pendidikan semakin baik; 6). Adanya keadilan dalam penyelenggaraan pendidikan; 7). Meningkatnya keterlibatan stakeholders; 8). Semakin baiknya iklim dan budaya kerja di sekolah; 9). Kesejahteraan guru dan staf sekolah membaik;10). Demokratisasi dalam penyelenggaraan pendidikan.

Kepala sekolah dalam kinerjanya dituntut untuk mampu menjalin kerja sama yang baik dengan para orang tua siswa yang tergabung dalam komite sekolah, karena sesuai dengan program pemerintah dalam menjalankan Manajemen Berbasis Sekolah, kepala sekolah diberi otonomi yang lebih luas dalam menyelenggarakan dan mengambil kebijakan yang berkaitan dengan peningkatan kualitas pembelajaran, pembenahan sarana dan prasarana pendukung sekolah dan kebijakan dalam merangkul mitra sekolah untuk melaksanakan segenap program sekolah. Dalam menjalankan tugas-tugas ini diharapkan kepala sekolah dapat merangkul Komite Sekolah sebagai mitra utama dalam melaksanakan semua program kerja yang telah dibuat. Beberapa penelitian terdahulu dengan tema yang sama banyak dilakukan hanya di satu sekolah sebagai lokasi penelitian. Pada penelitian ini mengkaji keterkaitan ketrampilan manajerial kepala sekolah dan peran komite dengan keberhasilan pelaksanaan manajemen berbasis sekolah pada beberapa sekolah yang telah dinyatakan berhasil melaksanakan MBS tersebut. Berdasarkan uraian diatas, tujuan penelitian ini adalah untuk mengetahui pengaruh ketrampilan manajerial kepala sekolah dan peran komite terhadap efektivitas manajemen berbasis sekolah di SD Negeri Se-Kecamatan Karangrejo.

\section{METODE}

Penelitian ini dilakukan dengan desain penelitian kuantitatif menggunakan metode survey yang terdiri atas dua variabel bebas, yaitu ketrampilan manajerial kepala sekolah (X1), peran komite sekolah (X2), dan variabel terikat yakni efektivitas Manajemen Berbasis Sekolah (Y). Untuk mendapatkan data primer dilapangan digunakan kuesioner yang disusun berdasarkan indikator-indikator yang ada dalam variabel penelitian. Penelitian ini difokuskan kepada sekolah yang sudah mendapat akreditasi A di Kecamatan Karangrejo yang terdiri dari 7 sekolah yaitu SDN 01 Karangrejo, SDN 03 Karangrejo, SDN 01 Tulungrejo, SDN 01 Bungur, SDN 02 Sukowidodo, SDN 03 Sukowidodo, dan SDN 01 Sukowiyono, dimana sampel dalam penelitian ini menggunakan sampel acak proposional (proportional random sampling) teknik pengambilan sampel menggunakan rumus Slovin dan diperoleh jumlah sampel 60 orang. Instrumen penelitian diuji tingkat validitas dan reliabilitas sebelum digunakan dalam pengambilan data. Data penelitian dianalisis melalui uji statistik diskriptif dengan kategori norma menurut Azwar dalam (Hanif Akhtar, 2018):

Tabel 1

Rumus Kategorisasi Subyek

\begin{tabular}{|c|c|}
\hline Kategori & Rumus \\
\hline Sangat Rendah & $X \leq \mu-1,5 \sigma$ \\
\hline Rendah & $\mu-1,5 \sigma<X \leq \mu-0,5 \sigma$ \\
\hline Sedang & $\mu-0,5 \sigma<X \leq \mu+0,5 \sigma$ \\
\hline Tinggi & $\mu+0,5 \sigma<X \leq \mu+1,5 \sigma$ \\
\hline Sangat Tinggi & $X>\mu+1,5 \sigma$ \\
\hline
\end{tabular}

Keterangan: $\mu$ : Mean $\sigma:$ Standar Deviasi

Sedangkan uji statistik inferensial dilakukan dengan Regresi Linier Berganda dengan persamaan:

$$
\mathrm{Y}=\alpha+\beta 1 \mathrm{X} 1+\beta 2 \mathrm{X} 2+\mathrm{e}
$$

Dimana :

$\mathrm{Y}=$ Efektivitas Manajemen Berbasis Sekolah

$\alpha=$ bilangan konstanta

$\mathrm{X} 1=$ Ketrampilan manajerial kepala sekolah

$\mathrm{X} 2$ = peran komite sekolah 


\section{$\beta 1=$ koefisien ketrampilan manajerial kepala sekolah} $\beta 2$ = koefisien peran komite sekolah

Pengujian hipotesis dalam penelitian ini menggunakan uji t (t-tes), uji $\mathrm{F}$ dan uji koefisien determinasi, sedangkan untuk memastikan kelayakan model dalam penelitian ini dilakukan uji asumsi klasik antara lain uji normalitas, uji multikolinieritas, dan uji heteroskedastisitas.

\section{HASIL DAN PEMBAHASAN}

\section{Analisis Diskriptif}

Penyajian statistic deskriptif hasil penelitian ini digunakan sebagai dasar untuk menguraikan kecenderungan jawaban responden dari tiap-tiap variabel baik mengenai ketrampilan manajerial kepala sekolah, komite sekolah dan efektivitas manajemen berbasis sekolah. Angket penelitian diberikan kepada 60 responden dengan total 60 item pernyataan, dengan rincian 20 item untuk penilaian ketrampilan manajerial kepala sekolah, 20 item pernyataan untuk peran komite sekolah dan 20 item pernyataan untuk efektivitas manajemen berbasis sekolah.

1. Keterampilan manajerial kepala sekolah

Kuesioner dari variabel ketrampilan manajerial kepala sekolah (X1) terdiri dari 20 item pernyataan yang masing-masing mempunyai 4 alternatif jawaban dengan rentang skor 1-4. Berdasarkan hasil perolehan angket ketrampilan manajerial kepala sekolah (X1) berikut disajikan data statistik hasil angket:

Tabel 2

Statistik Ketrampilan manajerial kepala sekolah $\left(\mathbf{X}_{1}\right)$ Statistics

\begin{tabular}{llr}
\hline Total & & \\
& Valid & 60 \\
\cline { 2 - 3 } & Missing & 0 \\
\hline Mean & 67.07 \\
\hline Std. Error of Mean & .800 \\
\hline Median & 67.00 \\
\hline Mode & 67 \\
\hline Std. Deviation & 6.194 \\
\hline Variance & 38.368 \\
\hline Range & 23 \\
\hline Minimum & 57 \\
\hline Maximum & 80 \\
\hline Sum & 4024 \\
\hline
\end{tabular}

Berdasarkan pada tabel 2 diperoleh nilai mean dari data X1 sebesar 67,07; median sebesar 67; modus sebesar 67; standar deviasi sebesar 6,194; dan varian sebesar 38,368. Sementara itu skor maksimum diperoleh sebesar 80 dan minimumnya sebesar 57.

Tabel 3

Data Hipotetik dan Empirik Variabel Ketrampilan Manajerial Kepala Sekolah

\begin{tabular}{|l|l|l|l|l|l|l|l|l|l|}
\hline \multicolumn{5}{|c|}{ Hipotetik } & \multicolumn{5}{c|}{ Empirik } \\
\hline $\begin{array}{l}\text { Nilai } \\
\text { Maks }\end{array}$ & $\begin{array}{l}\text { Nilai } \\
\text { Min }\end{array}$ & Mean & Range & $\begin{array}{l}\text { Standar } \\
\text { Deviasi }\end{array}$ & $\begin{array}{l}\text { Nilai } \\
\text { Maks }\end{array}$ & $\begin{array}{l}\text { Nilai } \\
\text { Min }\end{array}$ & Mean & Range & $\begin{array}{l}\text { Standar } \\
\text { Deviasi }\end{array}$ \\
\hline 80 & 20 & 50 & 60 & 10 & 80 & 57 & 67,07 & 23 & 6,194 \\
\hline
\end{tabular}

Dalam pengkategorisasi skala Ketrampilan Manajerial Kepala Sekolah, peneliti menggolongkan ke dalam lima kategori diagnosis Ketrampilan Manajerial Kepala Sekolah, pengkategorian subjek dilakukan dengan perhitungan manual norma kategorisasi sebagai berikut: 
DOI: https://doi.org/10.31004/basicedu.v5i3.970

Tabel 4

Kategorisasi Variabel Ketrampilan Manajerial Kepala Sekolah

\begin{tabular}{|l|c|c|c|}
\hline \multicolumn{1}{|c|}{ Kategori } & Interval Skor & Frekuensi & Persentase (\%) \\
\hline Sangat Rendah & $\mathrm{X} \leq 57,779$ & 6 & 10 \\
\hline Rendah & $57,779<\mathrm{X} \leq 63,973$ & 11 & 18,3 \\
\hline Sedang & $63,973<\mathrm{X} \leq 70,67$ & 14 & 23,3 \\
\hline Tinggi & $70,67<\mathrm{X} \leq 76,361$ & 27 & 45 \\
\hline Sangat Tinggi & $\mathrm{X}>76,361$ & 2 & 3,3 \\
\hline & Jumlah & 60 & 100 \\
\hline
\end{tabular}

Berdasarkan tabel 4 diketahui bahwa jumlah perolehan skor terendah terdapat pada nilai 57 yang besarnya $10 \%$ atau hanya 6 responden. Sedangkan perolehan skor dengan frekuensi paling banyak diperoleh sebesar 45\% atau sebesar 27 responden yaitu pada skor diantara 70,67 dan 76,361. Berdasarkan penilaian mayoritas responden tersebut disimpulkan bahwa Ketrampilan Manajerial Kepala Sekolah se Kecamatan Karangrejo dalam kategori tinggi

\section{Peran Komite Sekolah}

Angket variabel peran komite sekolah (X2) terdiri dari 20 item pernyataan yang masing-masing mempunyai 4 alternatif jawaban dengan rentang skor $1-4$. Berdasarkan hasil perolehan angket peran komite sekolah (X2) berikut disajikan data statistik hasil angket:

Tabel 5

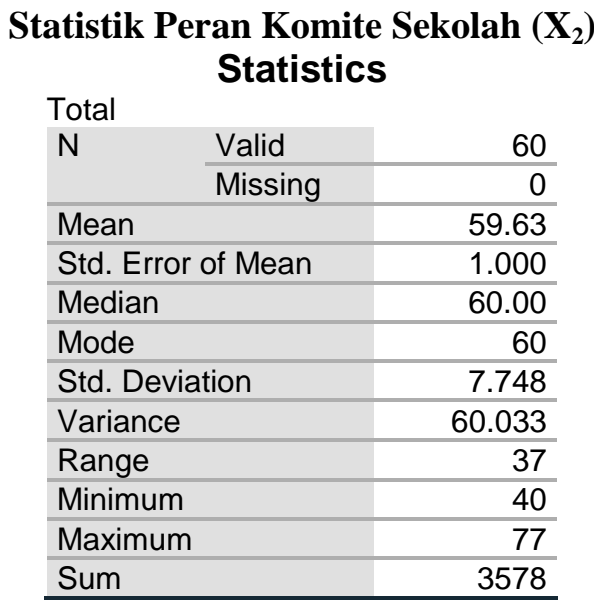

Berdasarkan pada tabel 5 diperoleh nilai mean dari data X2 sebesar 59,63; median sebesar 60; modus sebesar 60; standar deviasi sebesar 7,748; dan varian sebesar 60,033. Sementara itu skor maksimum diperoleh sebesar 77 dan minimumnya sebesar 40 .

\section{Tabel 6}

Data Hipotetik dan Empirik Variabel Peran Komite Sekolah

\begin{tabular}{|l|l|l|l|l|l|l|l|l|l|}
\hline \multicolumn{9}{|c|}{ Hipotetik } & \multicolumn{7}{|c|}{ Empirik } \\
\hline $\begin{array}{l}\text { Nilai } \\
\text { Maks }\end{array}$ & $\begin{array}{l}\text { Nilai } \\
\text { Min }\end{array}$ & Mean & Range & $\begin{array}{l}\text { Standar } \\
\text { Deviasi }\end{array}$ & $\begin{array}{l}\text { Nilai } \\
\text { Maks }\end{array}$ & $\begin{array}{l}\text { Nilai } \\
\text { Min }\end{array}$ & Mean & Range & S.D \\
\hline 80 & 20 & 50 & 60 & 10 & 77 & 40 & 59,63 & 37 & 7,748 \\
\hline
\end{tabular}

Dalam pengkategorisasi skala Peran Komite Sekolah, peneliti menggolongkan ke dalam lima kategori diagnosis Peran Komite Sekolah, pengkategorian subjek dilakukan dengan perhitungan manual yaitu dengan norma kategorisasi yang digunakan adalah: 
DOI: https://doi.org/10.31004/basicedu.v5i3.970

Tabel 7

Kategorisasi Variabel Peran Komite Sekolah

\begin{tabular}{|l|c|c|c|}
\hline \multicolumn{1}{|c|}{ Kategori } & Interval Skor & Frekuensi & $\begin{array}{c}\text { Persentase } \\
(\mathbf{\%})\end{array}$ \\
\hline Sangat Rendah & $\mathrm{X} \leq 48,008$ & 4 & 6,6 \\
\hline Rendah & $48,008<\mathrm{X} \leq 55,756$ & 9 & 15 \\
\hline Sedang & $55,756<\mathrm{X} \leq 63,504$ & 15 & 25 \\
\hline Tinggi & $63,504<\mathrm{X} \leq 71,252$ & 31 & 51,6 \\
\hline Sangat Tinggi & $\mathrm{X}>71,252$ & 1 & 1,6 \\
\hline & Jumlah & 60 & 100 \\
\hline
\end{tabular}

Berdasarkan tabel 7 diketahui bahwa jumlah perolehan skor terendah terdapat pada nilai 49 yang besarnya 6,6\% atau hanya 4 responden. Sedangkan perolehan skor dengan frekuensi paling banyak diperoleh sebesar 51,6\% atau sebesar 31 responden yaitu pada skor diantara 63,504 dan 71,252. Berdasarkan penilaian mayoritas responden tersebut disimpulkan bahwa Peran Komite Sekolahse Kecamatan Karangrejo dalam kategori tinggi.

3. Efektivitas Manajemen Berbasis Sekolah

Angket variabel Efektivitasmanajemen berbasis sekolah (Y) terdiri dari 20 item pernyataan yang masing-masing mempunyai 4 alternatif jawaban dengan rentang skor $1-4$. Berdasarkan hasil perolehan angket efektivitasmanajemen berbasis sekolah (Y) berikut disajikan data statistik hasil angket:

Tabel 8

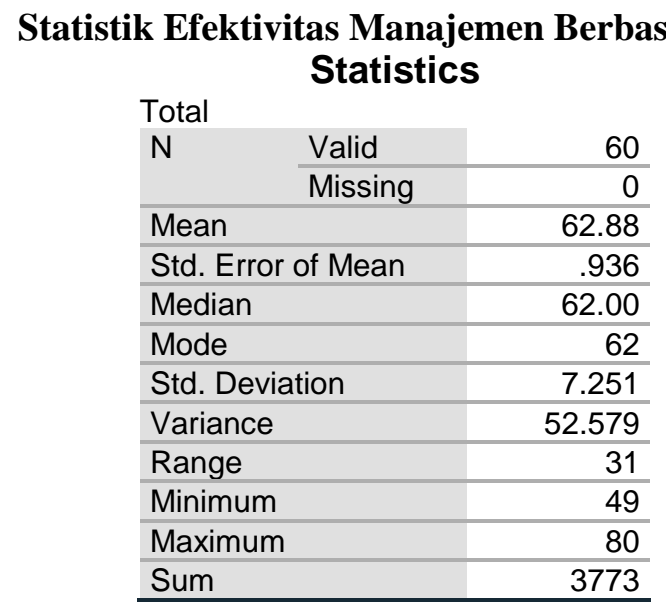

Berdasarkan pada tabel 8 diperoleh nilai mean dari data Y sebesar 62,88; median sebesar 62; modus sebesar 62; standar deviasi sebesar 7,251; dan varian sebesar 52,579. Sementara itu skor maksimum diperoleh sebesar 80 dan minimumnya sebesar 49 .

Tabel 8

Data Hipotetik dan Empirik Variabel Efektivitas manajemen berbasis sekolah

\begin{tabular}{|c|c|c|c|c|c|c|c|c|c|}
\hline \multicolumn{5}{|c|}{ Hipotetik } & \multicolumn{6}{c|}{ Empirik } \\
\hline $\begin{array}{l}\text { Nilai } \\
\text { Maks }\end{array}$ & $\begin{array}{l}\text { Nilai } \\
\text { Min }\end{array}$ & Mean & Range & $\begin{array}{l}\text { Standar } \\
\text { Deviasi }\end{array}$ & $\begin{array}{l}\text { Nilai } \\
\text { Maks }\end{array}$ & $\begin{array}{l}\text { Nilai } \\
\text { Min }\end{array}$ & Mean & Range & S.D \\
\hline 80 & 20 & 50 & 60 & 10 & 80 & 49 & 62,88 & 31 & 7,251 \\
\hline
\end{tabular}

Dalam pengkategorisasi skala efektivitas manajemen berbasis sekolah, peneliti menggolongkan ke dalam lima kategori diagnosis efektivitas manajemen berbasis sekolah, pengkategorian subjek dilakukan dengan perhitungan manual yaitu dengan orma kategorisasi yang digunakan adalah: 
Tabel 9

Kategorisasi Variabel efektivitas manajemen berbasis sekolah

\begin{tabular}{|l|c|c|c|}
\hline \multicolumn{1}{|c|}{ Kategori } & Interval Skor & Frekuensi & Persentase (\%) \\
\hline Sangat Rendah & $\mathrm{X} \leq 48,008$ & 3 & 5 \\
\hline Rendah & $48,008<\mathrm{X} \leq 55,756$ & 8 & 13 \\
\hline Sedang & $55,756<\mathrm{X} \leq 63,504$ & 16 & 26,6 \\
\hline Tinggi & $63,504<\mathrm{X} \leq 71,252$ & 30 & 50 \\
\hline Sangat Tinggi & $\mathrm{X}>71,252$ & 3 & 5 \\
\hline & Jumlah & 60 & 100 \\
\hline
\end{tabular}

Berdasarkan tabel 9 diketahui bahwa jumlah perolehan skor terendah terdapat pada nilai kurang dari 48 yang besarnya $5 \%$ atau hanya 3 responden. Sedangkan perolehan skor dengan frekuensi paling banyak diperoleh sebesar 50\% atau sebesar 30 responden yaitu pada skor diantara 63,504 dan 71,252. Berdasarkan penilaian mayoritas responden tersebut disimpulkan bahwa efektivitas manajemen berbasis sekolah se Kecamatan Karangrejo dalam kategori tinggi.

\section{Uji Regresi Linier Berganda}

Hasil statistik melalui uji regresi berganda pada penelitian ini didapat hasil seperti tabel 10:

\section{Tabel 10}

Ringkasan Hasil Regresi Linier Berganda

\begin{tabular}{|l|r|r|r|r|}
\hline \multicolumn{1}{|c|}{ Variabel } & \multicolumn{1}{c|}{ Koef. Regresi } & \multicolumn{1}{c|}{ Std. error } & t. stat & \multicolumn{1}{c|}{ sig } \\
\hline $\begin{array}{l}\text { Ketrampilan Manajerial Kepala } \\
\text { Sekolah }\end{array}$ & 0,568 & 0,226 & 3.864 & 0,000 \\
\hline Peran Komite Sekolah & & & & \\
\hline Konstanta & 0,368 & 0,132 & 2.892 & 0,013 \\
\hline
\end{tabular}

Dependent variable: Efektivitas MBS

\begin{tabular}{|l|l|}
\hline Multiple R & 0,66319 \\
\hline R square & 0,63318 \\
\hline Adjusted R. Square & 0,62402 \\
\hline Standart Error & 46,67638 \\
\hline F. stat & 11,4539 \\
\hline Durbin Watson Test & 1,85715 \\
\hline
\end{tabular}

Sumber : print out hasil perhitungan statistik

Dari tabel di atas dapat dibuat persamaan regresi linier berganda sebagai berikut :

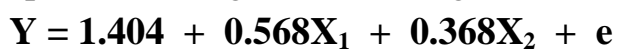

Persamaan di atas mempunyai arti bahwa jika Ketrampilan Manajerial Kepala Sekolah $\left(\mathrm{X}_{1}\right)$ naik satu satuan, maka Efektivitas MBS (Y) akan naik sebesar 0.568 satuan dengan anggapan variabel yang lain konstan. Jika Peran Komite Sekolah $\left(\mathrm{X}_{2}\right)$ naik satu satuan, maka Efektivitas MBS (Y) akan naik sebesar 0.368 satuan dengan anggapan variabel yang lain konstan. Nilai R sebesar 0.633 berarti bahwa hubungan antara variabel-variabel bebas ketrampilan manajerial kepala sekolah dan peran komite sekolah terhadap variabel terikat yaitu Efektivitas MBS adalah erat dan kuat. Hal ini ditandai dengan nilai R di atas $50 \%$ yaitu sebesar 63,3\%. Nilai determinasi simultan (R square) sebesar 0,633 artinya bahwa variasi berubahnya Efektivitas MBS dipengaruhi oleh ketrampilan manajerial kepala sekolah dan peran komite sekolah sebesar 63,3\% sedangkan sisanya sebesar 36,7\% dipengaruhi oleh variabel lain yang tidak diteliti.

\section{Pengujian Hipotesis Pertama}

Hipotesis yang pertama adalah diduga terdapat pengaruh signifikan antara variabel ketrampilan manajerial kepala sekolah dan peran komite sekolah secara bersama-sama (simultan) terhadap variabel efektivitas MBS. 
1572 Pengaruh Keterampilan Manajerial Kepala Sekolah Dan Peran Komite Terhadap Efektivitas Manajemen Berbasis Sekolah - Suyitno

DOI: https://doi.org/10.31004/basicedu.v5i3.970

Tabel 11

Hasil Perhitungan Uji Simultan (Uji F)

ANOVA $^{\mathrm{D}}$

\begin{tabular}{|l|l|l|l|l|l|}
\hline Model & Sum of Squares & $\mathrm{df}$ & Mean Square & $\mathrm{F}$ & Sig. \\
\hline \multirow{4}{*}{$\begin{array}{l}\text { Regression } \\
\text { Residual }\end{array}$} & 15.540 & 2 & 7.770 & 11,453 & $.000^{\mathrm{a}}$ \\
& 26.460 & 58 & 4.285 & & \\
Total & 42.000 & 60 & & & \\
\hline
\end{tabular}

a. Predictors: (Constant), Manaj, Komite

b. Dependent Variable: MBS

Perhitungan regresi linier berganda menghasilkan nilai $\mathrm{F}_{\text {hitung }}$ sebesar $11.453 \mathrm{~F}_{\text {tabel }}$ sebesar 2.98 dengan df pembilang 2 dan penyebut 60. Dengan demikian maka terbukti bahwa $F_{\text {hitung }}$ lebih besar daripada $F_{\text {tabel }}$ yang berarti Ho ditolak dan menerima Ha pada tingkat signifikansi sebesar 0.000. Artinya bahwa terdapat pengaruh yang signifikan variabel-variabel ketrampilan manajerial kepala sekolah dan peran komite sekolah secara bersama-sama (simultan) terhadap efektivitas MBS.

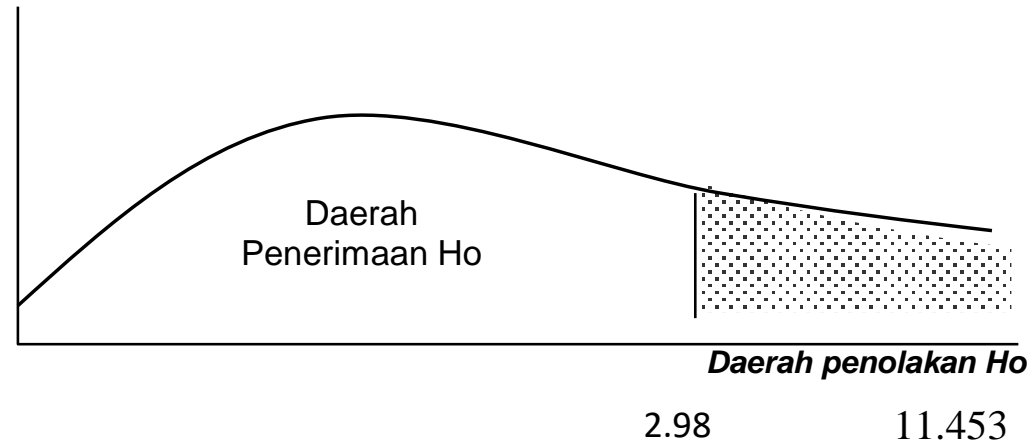

Gambar 1. Daerah Penolakan Ho Pada Uji F

\section{Pengujian Hipotesis Kedua}

Hipotesis yang kedua adalah diduga terdapat pengaruh signifikan antara variabel ketrampilan manajerial kepala sekolah dan peran komite sekolah secara parsial terhadap variabel efektivitas MBS. Pengujian hipotesis yang kedua ini dengan menggunakan uji t.

Tabel 12

Hasil Perhitungan Uji-t

Coefficients $^{a}$

\begin{tabular}{|c|c|c|c|c|c|c|}
\hline \multirow{2}{*}{\multicolumn{2}{|c|}{ Model }} & \multicolumn{2}{|c|}{$\begin{array}{l}\text { Unstandardized } \\
\text { Coefficients }\end{array}$} & \multirow{2}{*}{$\begin{array}{c}\text { Standardized } \\
\text { Coefficients }\end{array}$} & \multirow[b]{2}{*}{$\mathrm{t}$} & \multirow[b]{2}{*}{ Sig. } \\
\hline & & $\mathrm{B}$ & Std. Error & & & \\
\hline \multirow[t]{3}{*}{1} & (Constant) & 1.404 & .561 & & .752 & .457 \\
\hline & Manaj KS & 0.568 & .226 & .510 & 3.864 & .000 \\
\hline & Komite S & 0.368 & .132 & .351 & 2.892 & .013 \\
\hline \multicolumn{3}{|c|}{ a. Dependent Variable: $Y$} & & & & \\
\hline
\end{tabular}

Derajat kebebasan $\mathrm{df}=(\mathrm{n}-\mathrm{k}-1)=60-2-1=57$ dan tingkat taraf kepercayaan $5 \%$ atau 0.05 , maka nilai $\mathrm{t}_{\text {tabel }}$ adalah sebesar 2.056. Adapun penjelasan pada masing-masing variabel sebagai berikut:

1. Variabel ketrampilan manajerial kepala sekolah (X1)

Nilai $t_{\text {hitung }}$ dalam penelitian ini adalah sebesar 3.864 dengan tingkat signifikansi sebesar 0.000 lebih besar dari $t_{\text {tabel }}$ sebesar 2.056. Hal ini menunjukkan bahwa terjadi penolakan Ho dan penerimaan Ha yang berarti terdapat pengaruh yang signifikan variabel ketrampilan manajerial kepala sekolah terhadap variabel efektivitas MBS. 


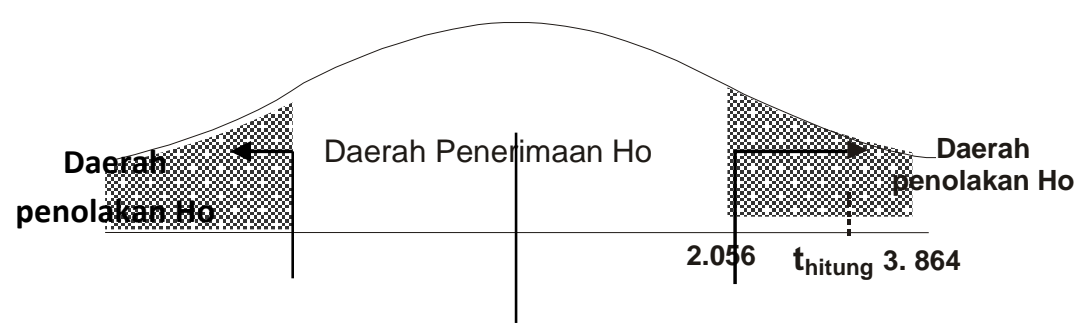

Gambar 2. Daerah Penolakan Ho Pada Uji t (2-tail) Variabel ketrampilan manajerial kepala sekolah $\left(\mathbf{X}_{1}\right)$

Pengaruh ketrampilan manajerial kepala sekolah terhadap keberhasilan MBS menunjukkan hasil koefisien regresi yang bertanda positif dan signifikan. Hal ini menunjukkan bahwa pelaksanaan manajemen berbasis sekolah akan memiliki peningkatan efektivitas secara nyata jika didukung dengan kompetensi ketrampilan manajerial Kepala sekolah yang tinggi pula.

2. Peran Komite Sekolah $\left(\mathrm{X}_{2}\right)$

Nilai $t_{\text {hitung }}$ dalam untuk variabel ini ini adalah sebesar 2.892 dengan tingkat signifikansi sebesar 0.013 lebih besar dari $\mathrm{t}_{\text {tabel }}$ sebesar 2.056. Hal ini menunjukkan bahwa terjadi penolakan Ho dan penerimaan Ha yang berarti terdapat pengaruh yang signifikan variabel peran komite sekolah terhadap variabel efektivitas MBS.

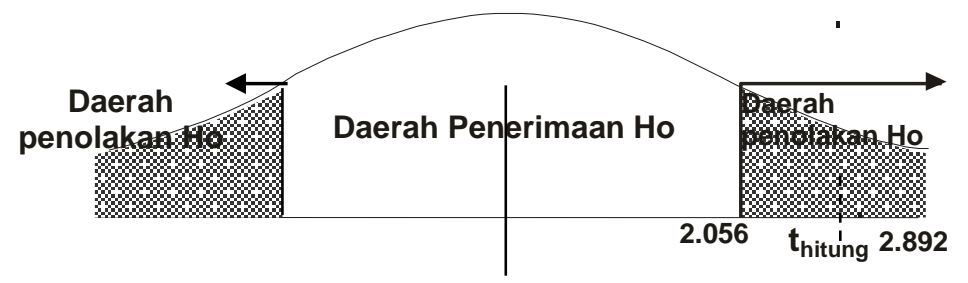

\section{Gambar 3. Daerah Penolakan Ho Pada Uji t (2-tail) Variabel peran komite sekolah $\left(\mathbf{X}_{2}\right)$}

Peran komite sekolah memiliki pengaruh positif dan signifikan terhadap efektivitas Manajemen Berbasis Sekolah. Hal ini dapat disimpulkan bahwa jika peran komite sekolah antara lain sebagai Badan Pertimbangan (Advisory Agency), badan pendukung (Supporting Agency), badan pengontrol (Controlling Agency) dan badan penghubung (Mediator Agency) diterapkan secara maksimal akan meningkatkan efektivitas atau keberhasilan pelaksanaan manajemen berbasis sekolah.

\section{Pengujian Hipotesis Ketiga}

Selanjutnya, untuk pengujian hipotesis yang ketiga adalah melihat variabel mana diantara variabel bebas yang berpengaruh dominan terhadap variabel terikat. Untuk lebih jelasnya dapat disajikan pada tabel 13:

Tabel 13

Perbandingan nilai $t_{\text {hitung }}$ dari dua variabel bebas

\begin{tabular}{|c|c|c|c|}
\hline Model & $t_{\text {hitung }}$ & Sig & Keterangan \\
\hline $\begin{array}{l}1 \text { Ketrampilan Manajerial KS (X1) } \\
\text { Peran Komite Sekolah (X2) }\end{array}$ & $\begin{array}{l}3.864 \\
2.892\end{array}$ & $\begin{array}{l}0.000 \\
0.013\end{array}$ & Dominan \\
\hline
\end{tabular}

Dari tabel di atas dapat dilihat bahwa secara parsial seluruh variabel ketrampilan manajerial kepala sekolah (X1) dan peran komite sekolah (X2) berpengaruh terhadap variabel terikat (efektivitas MBS). Namun berdasarkan nilai $\mathrm{t}$ yang dimiliki kedua variabel yang diteliti seperti terlihat pada tabel diatas, bahwa nilai $\mathrm{t}$ dari ketrampilan manajerial kepala sekolah $\left(\mathrm{t}_{\text {hitung }}=3.864\right)$ lebih besar dan bernilai positif dibandingkan dengan peran komite sekolah $\left(\mathrm{t}_{\text {hitung }}=2.892\right)$. Dengan demikian dapat disimpulkan bahwa ketrampilan 
manajerial kepala sekolah mempunyai pengaruh yang dominan terhadap efektivitas manajemen berbasis sekolah.

Berdasarkan hasil penelitian yang menganalisis pengaruh ketrampilan dan peran komite sekolah terhadap efektivitas menejemen berbasis sekolah dapat ditunjukkan pada gambar 4.

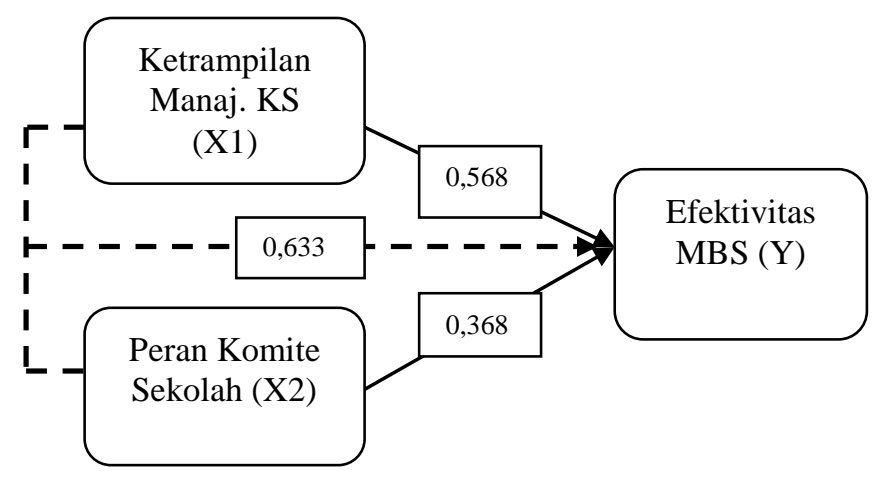

Gambar 4. Hasil Model Penelitian

Pada gambar 4 menunjukan bahwa pengaruh ketrampilan manajerial kepala sekolah terhadap efektivitas MBS sesuai koefisien regresi sebesar 0,568 atau 56,8\% dengan taraf signifikansi 0,000, yang berarti bahwa ketrampilan manajerial kepala sekolah yang baik berdampak pada efektivitas MBS di SDN se-Karangrejo. Hal Ini dapat diinterpretasikan bahwa jika ketrampilan manajerial kepala sekolah baik dan mampu mengoptimalkan sumberdaya di sekolah yang dipimpinnya, maka keberhasilan MBS akan meningkat. Hasil penelitian ini sejalan dengan hasil penelitian (Eka Yuli Astuti, 2021) yang menyatakan bahwa Kemampuan manajerial memiliki pengaruh yang positif dan signifikan terhadap kualitas penerapan manajemen berbasis sekolah di SMA se-Kecamatan Makarti Jaya. Diantara beberapa kompetensi yang dipersyaratkan sebagai kepala sekolah, kompetensi manajerial kepala sekolah selaku pemimpin pendidikan merupakan salah satu komponen penting dalam meningkatkan program pendidikan di sekolah yang selama ini sudah berjalan yaitu manjemen berbasis sekolah.

Selanjutnya, berdasarkan temuan penelitian perang komite sekolah (X2) berpengaruh positif dan signifikan terhadap efektivitas MBS sesuai dengan koefisien regresi yang didapat sebesar 0,368 atau 36,8\% dengan taraf signifikansi 0,013 . Hal ini diinterpretasikan bahwa jika komite sekola bekerja sesuai perannya maka efektivitas MBS juga akan meningkat. Hasil penelitian ini sejalan dengan hasil penelitian Siregar (2020) yang menyatakan bahwa pengaruh peran komite sekolah terhadap efektivitas MBS di MAN kota Medan yaitu sebesar 18,7\%; Hubungan yang harmonis antar sekolah dan masyarakat yang diwadahi dalam organisasi komite sekolah. Partisipasi masyarakat dalam bentuk ide dan gagasan, materi, dukungan moral, pemberian akses, dan lain sebagainya sangat penting demi peningkatan kualitas dan kebesaran sekolah. Sekolah besar tidak lepas dari andil masyarakat dalam memberikan dukungan baik moral maupun material. Oleh karena itu, hubungan sekolah dan masyarakat merupakan salah satu komponen penting dalam keseluruhan kerangka penyelenggaraan pendidikan.

Kedua variabel bebas tersebut yakni ketrampilan manajerial kepala sekolah (X2) dan peran komite (X2) dapat menerangkan pengaruhnya secara bersama-sama terhadap efektivitas MBS sebesar 0,633 atau 63,3\% dengan taraf signifikansi 0,000. Hal ini menggambarkan pengaruh yang cukup besar karena lebih dari 50\%, yang berarti bahwa kedua variabel tersebut sangat penting dan menentukan dalam keberhasilan pelaksanaan Manajemen Berbasis Sekolah di SD se Kecamatan Karangrejo.

Berdasarkan temuan penelitian yang ditunjukkan dari hasil uji hiptesis denan variabel-variabel ketrampilan manajerial kepala sekolah dan peran komite yang dikaitkan dengan efektivitas MBS masih perlu diteliti lebih lanjut dalam kancah yag lebih luas lagi. Lokasi pada penelitian ini dipilih pada sekolah-sekolah 
yang telah terakreditasi A, artinya bahwa sekolah yang menjadi obyek penelitian sudah mengimplementasikan MBS dengan baik. Hal ini yang membedakan dengan penelitian-penelitian sejenis sebelumnya.

\section{KESIMPULAN}

Berdasarkan hasil penelitian yang dilakukan, maka dapat diambil kesimpulan sebagai berikut: 1) Ketrampilan manajerial kepala sekolah berpengaruh positif dan signifikan terhadap efektivitas manajemen berbasis sekolah di SD Negeri Se-Kecamatan Karangrejo; 2) Komite sekolah berpengaruh positif dan signifikan terhadap efektivitas manajemen berbasis sekolah di SD Negeri Se-Kecamatan Karangrejo; 3) Ketrampilan manajerial kepala sekolah dan peran komite secara bersama-sama berpengaruh positif dan signifikan terhadap efektivitas manajemen berbasis sekolah di SD Negeri Se-Kecamatan Karangrejo; 4) Ketrampilan manajerial kepala sekolah berpengaruh dominan terhadap efektivitas manajemen berbasis sekolah di SD Negeri Se-Kecamatan Karangrejo

\section{DAFTAR PUSTAKA}

Arar, K., \& Nasra, M. A. (2020). Linking school-based management and school effectiveness: The influence of self-based management, motivation and effectiveness in the Arab education system in Israel. Educational Management Administration \& Leadership, 48(1), 186-204. https://doi.org/10.1177/1741143218775428

Ariyanti, N. S., Sobri, A. Y., \& Kusumaningrum, D. E. (2018). Kepemimpinan Kepala Sekolah Dalam Meningkatkan Partisipasi Masyarakat. Jurnal Administrasi dan Manajemen Pendidikan, 1(1), 1-6. https://doi.org/10.17977/um027v1i12018p1

Atiek Istijarti, Y. R. (2019). Implementation of Management Based School in Improving the Quality of Secondary Education. International Journal for Educational and Vocational Studies, 1(8), 904-907.

Basith, A. (2020). Kontribusi Kinerja Komite Sekolah Terhadap Peningkatan Mutu Sarana Prasarana Pendidikan. J-MPI (Jurnal Manajemen Pendidikan Islam) p ISSN: 2477-4987| e ISSN: 2477-6467, 5(1), 12.

Eka Yuli Astuti, T. (2021). Pengaruh Kemampuan Manajerial dan Motivasi Kerja Kepala Sekolah Terhadap Kualitas Penerapan Manajemen Berbasis Sekolah. JMKSP (Jurnal Manajemen, Kepemimpinan, dan Supervisi Pendidikan), 6(1), 140-147.

Hanif Akhtar. (2018). Cara Membuat Kategorisasi Data Penelitian dengan SPSS. Tutorial Analisis Data Online. https://www.semestapsikometrika.com/2018/07/membuat-kategori-skor-skala-dengan-spss.html

Hodin. (2020). Manajemen Berbasis Sekolahdalam Meningkatkan Mutu Pendidikandi Smp Negeri 02 Purworejo. E-journal, Cakrawla: Studi Manajemen Pendidikan Islam Dan Studi Sosial, 4(1), 51-68.

Ibrahim. (2015). Implementasi Manajemen Berbasis Sekolah Pada SD Negeri Sakti Pidie. Jurnal Administrasi Pendidikan Pascasarjana Universitas Syiah Kuala, 3(1), 116-125.

Iskandar, J. (2017). Keterampilan Manajerial Kepala Sekolah. Jurnal Idaarah, 1(1), 7.

Marsofiyati, M., \& Febriantina, S. (2016). Pemberdayaan Komite Sekolah Dalam Meningkatkan Efisiensi Pengelolaan Sekolah Di Kota Depok (Studi Kasus pada Komite SMAIT Al-Qudwah Kota Depok). Econosains Jurnal Online Ekonomi dan Pendidikan, 14(2), 79-98. https://doi.org/10.21009/econosains.0142.09

Pakniany, N. S. L., Imron, A., \& Degeng, I. N. S. (2020). Peran Serta Masyarakat Dalam Penyelenggaraan Pendidikan. Jurnal Pendidikan: Teori, Penelitian, dan Pengembangan, 5(3), 8.

Siregar, F. A. (2018). Peningkatan Kompetensi Kepala Sekolah Dalam Upaya Meningkatkan Mutu Pendidikan. Jurnal IJTIMAIYAH, 2(1), 15-25. 
1576 Pengaruh Keterampilan Manajerial Kepala Sekolah Dan Peran Komite Terhadap Efektivitas Manajemen Berbasis Sekolah - Suyitno

DOI: https://doi.org/10.31004/basicedu.v5i3.970

Siregar, G. G. S. (2020). Pengaruh kepemimpinan kepala sekolah, peran komite sekolah dan kinerja guru terhadap efektivitas manajemen berbasis sekolah di MAN Kota Medan. Jurnal EduTech Vol. 6 No. 2 September 2020.

Siti Aminah, M. A. (2015). Implementasi Manajemen Berbasis Sekolah Dalam Meningkatkan Mutu Pendidikan Pada Mtsn Kota Lhokseumawe. Jurnal Administrasi Pendidikan Pascasarjana Universitas Syiah Kuala, 3(2), 1-11.

Sunanto. (2015). Implementasi Manajemen Berbasis Sekolah Dalam Peningkatan Mutu Pendidikan Pada Smp Negeri 19 Percontohan Banda Aceh. INTELEKTUALITA - Volume 3, Nomor 1, Januari-Juni 2015 https://jurnal.ar-raniry.ac.id/index.php/intel/article/view/199/180

Syamsudin, S. (2017). Penerapan Fungsi-Fungsi Manajemen Dalam Meningkatkan Mutu Pendidikan. Idaarah: Jurnal Manajemen Pendidikan, 1(1). https://doi.org/10.24252/idaarah.v1i1.4084 